\title{
RESTORATIVE JUSTICE AND CASES OF SERIOUS OFFENDING: A SOUTH AFRICAN AND CANADIAN PERSPECTIVE
}

\author{
Emma Charlene Lubaale \\ LLB LLM LLD \\ Senior Lecturer, Department of Jurisprudence \\ School of Law, University of Venda
}

\begin{abstract}
SUMMARY
The exact meaning, place and role of "restorative justice" (hereinafter "RJ") in criminal matters remain largely unclear. Often, $\mathrm{RJ}$ is reduced to a sentencing option, an alternative to retributive justice and an approach, which cannot co-exist alongside custodial sentences. This oversimplification of the concept of RJ seems to have trickled down to the decisions of courts. Notably, although over the years the use of $\mathrm{RJ}$ in criminal matters has grown in its stature and impact, with countries like Canada and South Africa constituting prime examples of the few embracing this system in criminal matters, a critical analysis of the jurisprudence of both countries reveals that its application to criminal matters is shrouded with ambiguity. Most of these courts have reduced $\mathrm{RJ}$ to a mere sentencing option, an option that cannot rest comfortably alongside custodial sentences and an alternative to retributive justice. Nowhere is this ambiguity more eminent than in cases of serious offending. Given that custodial sentences are often deemed relevant in cases of serious offending, when RJ is oversimplified, it is often excluded from the overall criminal justice framework, making it impossible for it to co-exist alongside a retributive system of justice. Put differently, the manner in which RJ is being conceptualised is having major implication for its role in the prosecution of cases of serious offending. This article analyses case law that grapples with these issues in Canada and South Africa and on the basis of this analysis, it is argued that for RJ to have a meaningful role, especially in cases of serious offending, it should be perceived as a guiding principle that provides a foundation in the overall criminal justice process rather than a mere sentencing option, an alternative and an approach totally against custodial sentences.
\end{abstract}

\section{INTRODUCTION}

Precisely defining the term "restorative justice" is fraught with difficulty. The term has been used in different contexts and disciplines based on the variances in its use; the meaning attached to it has also varied. Some commentators prefer to use the term "restorative justice" to call into question 
the objectives and methods of retributive criminal justice. ${ }^{1}$ In some instances, RJ has been used to describe transformational or transitional justice mechanisms such as those applied in truth and reconciliation commissions. ${ }^{2}$ Across the literature, the overlapping values underpinning $R J$ include victim participation, repairing of harm caused to victims, reconciliation or making amends, guarantees against repetition of crime, etcetera. ${ }^{3}$ Repairing the harm caused to victims may encompass the offender compensating, apologizing and making restitution to the victim. In principle, all parties with a stake in a given crime including the victim, offender and in some instances community members are given a platform to participate actively in addressing the issues surrounding the commission of a crime. ${ }^{4}$ Through this platform, the offender is given an opportunity to take responsibility for the crime committed and for the victim to actively participate in dispute resolution.

Although there are some cross-cutting features amongst most experts on what RJ constitutes, some ambiguities remain, in particular, how RJ is conceptualized. Several issues remain controversial including whether RJ is the better system of justice when compared to retributive justice, whether RJ encompasses punishment in the form of custodial sentences and whether RJ should find relevance in cases of serious offending. With regard to the first controversy, the arguments of some experts, especially earlier commentators on the subject of RJ, mainly focused on a contrast between the retributive justice model and the RJ model. ${ }^{5} \mathrm{~A}$ review of the literature, particularly by earlier commentators reveals that they were preoccupied with differentiating RJ from retributive justice, with commentators pitting one model of justice against the other. ${ }^{6}$ In subsequent years, however, some

1 Mika and Zehr "A Restorative Justice Framework for Community Justice Practice" in McEvoy and Newburn (eds) Criminology, Conflict Resolution and Restorative Justice (2003) 138.

2 Coben and Harley "International Conversations about Restorative Justice, Mediation and The Practice of Law" 200425 Hamline J. Pub L \& Policy 235239.

3 Skelton “Juvenile Justice Reform: Children's Rights and Responsibilities versus Crime Control" in Davel (ed) Children's Rights in a Transitional Society (1999) 93-94; Zehr Changing Lenses - A New Focus for Crime and Justice 3ed (2005) 271; Marshal "The Evolution of Restorative Justice in Britain" 19964 European Journal of Criminal Policy \& Research 21 37; Batley "Ngwana Phosa Dira ga a Bolawe: The Value of Restorative Justice to the Reintegration of Offenders" 200821 SA Crime Quarterly 27; Mousourakis "Restorative Justice: Some Reflections on Contemporary Theory and Practice" 200429 Journal for Juridical Science 12 ; Tshehla "The Restorative Justice Bug Bites the South African Criminal Justice System" 200417 SACJ 1-16; Bezuidenhout "Restorative Justice with an Explicit Rehabilitative Ethos: Is this the Resolve to Change Criminality?" 200720 Acta Criminologica 43 44; Daly Conventional and Innovative Justice Responses to Sexual Violence: Australian Centre for the Study of Sexual Assault (2011) 11; Hargovan "Book Review: Restorative Justice and Victimology: Euro-Africa Perspectives" 201343 SA Crime Quarterly 39-41; Zehr and Mika "Fundamental Concepts of Restorative Justice" 19981 Contemporary Justice Review 47-55.

Zehr Changing Lenses - A New Focus for Crime and Justice 271.

5 See eg, Zehr Changing Lenses: A New Focus for Crime and Justice 1ed (1990).

6 Zehr Changing Lenses: A New Focus for Crime and Justice (1990). There also some more recent or not so old literature that still invokes this earlier view. See eg, Lofty "Restorative Justice - A New Approach to Conflict Resolution" 2016 http://restorativejustice.org/rjlibrary/restorative-justice-a-new-approach-to-conflict-resolution/2015/ (accessed 2017-01 05); Caine "Cook County Court to Try New Approach to Justice" 2016 
commentators abandoned such sharp polarization, with prominent adherents of RJ such as Zehr conceding that such dichotomy was misleading and warranting of rejection. ${ }^{7}$ Other commentators such as Roche and Daly endorsed the foregoing viewpoint, contending that such oversimplification distorts both approaches of justice.

On the second controversial issue - whether RJ encompasses punishment, some commentators advance the viewpoint that $\mathrm{RJ}$ entirely excludes punishment in the form of custodial sentences. ${ }^{9}$ Other commentators are, however, of the opinion that RJ does not and should not necessarily exclude punishment. ${ }^{10}$ Notably, although the arguments of earlier commentators had created some sort of dichotomy between the retributive justice model and the $\mathrm{RJ}$ model, contemporary commentators on RJ started advancing arguments thought to help strike a balance between retributive justice and RJ. Schiff et al, for instance, devoted an entire book to this cause ${ }^{11}$ with contributors to this volume such as Duff advancing a firm argument that RJ should include punishment. ${ }^{12}$ Some commentators writing on RJ in South Africa have endorsed the foregoing position, one such notable one being Hargovan who takes the view that "unless punitive outcomes are allowed to be part of [restorative justice], the use of restorative approaches such as alternative dispute resolution processes will never be an accepted practice in criminal justice." ${ }^{13}$

Aside from the above controversies, it also remains largely unclear whether or not RJ should find relevance in cases of serious offending.

http://chicagotonight.wttw.com/2016/05/16/cook-county-court-try-new-approach-justice (accessed 2017-01-05).

7 Zehr "Journey to Belonging" in Weitekamp and Kerner (eds) Restorative Justice:Theoretical Foundations (2002).

8 Roche "Retribution and Restorative Justice" in Gerry and Van Ness (eds) Handbook on Restorative Justice (2007); Daly "Sexual Assault and Restorative Justice" in Strang and Braithwaite (eds) Restorative Justice and Family Violence (2002); Daly Conventional and Innovative Justice Responses to Sexual Violence: Australian Centre for the Study of Sexual Assault; Curtis-Fawley and Daly "Gendered Violence and Restorative Justice: The Views of Victim Advocates" 200511 Violence Against Women 603-638. Curtis-Fawley and Daly, for instance, submit that critiques of RJ often fall into the trap of giving this concept a too literal interpretation. According to Daly, the "lack of agreement on definition means that restorative justice has not one but many identities and referents; and this can create theoretical empirical, and policy confusion." This confusion bug appears to continue biting several criminal justice systems in recent times and consequently impacting negatively on the application of RJ; Daly "The Limits of Restorative Justice" in Sullivan and Tifft (eds) Handbook of Restorative Justice: A Global Perspective (2006) 134 135; Daly Restorative Justice: Moving Past the Caricatures (Paper presented to Seminar on Restorative Justice, Institute of Criminology, Sydney, April 1998).

9 See eg, earlier arguments of commentators like Zehr Changing Lenses: A New Focus for Crime and Justice (1990).

10 Daly "Does Punishment have a place in Restorative Justice?" https://www.griffith.edu.au/ data/assets/pdf_file/0016/50326/kdpaper7.pdf (accessed 2017-01-05).

11 Schiff, von Hirsch and Roberts Restorative Justice and Criminal Justice: Competing or Reconcilable Paradigms? (2003).

12 Duff "Restoration and Retribution" in von Hirsch et al (eds) Restorative Justice and Criminal Justice: Competing or Reconcilable Paradigms (2003).

13 Hargovan Restorative Approaches to Criminal Justice: An Exploratory Study in KwaZuluNatal (Unpublished doctoral thesis, University of KwaZulu-Natal South Africa 2008) 27. 
According to one line of argument, cases of serious offending are unsuited for the application of RJ. ${ }^{14}$ Opponents are particularly sceptical about the role of RJ in very grave offences such as terrorism, murder and rape. ${ }^{15}$ Some view restorative initiatives as a too lenient response, a soft option, and a form of cheap justice or an easy way out for offenders. ${ }^{16}$ Concerns have also been raised about the appropriateness of $\mathrm{RJ}$ in cases of sexual offending and domestic violence. ${ }^{17}$ Opponents contend that the power imbalances in communities may influence negatively on the outcomes of the RJ process; leading some rights groups to conclude, "there are offenders who are not appropriate candidates for such programs". ${ }^{18}$ For some rights groups, "[e]ven if an offender participates in a RJ program, he/she may still be dangerous and therefore must still be sent to prison". ${ }^{19}$ According to another line of argument, RJ should find relevance in all criminal matters, including cases of serious offending. ${ }^{20}$ Some commentators are even of the opinion that the RJ approach should be applied in cases of sexual offending. ${ }^{21}$ Adherents are of the opinion that RJ should be invoked more in cases of serious offending because it gives victims and offenders an opportunity to meet each other, in particular for the victim to express their

14 See eg, Cossins Alternative Models for Prosecuting Child Sex Offences in Australia: Report of the National Child Sexual Assault Reform Committee (2010) 365; Bezuidenhout 200720 Acta Criminologica 56; Acorn Compulsory Compassion: A Critique of Restorative Justice (2004) 47; Libin "Sentencing Circles for Aboriginals: Good Justice?" 27 February 2009 National Post http://www.nationalpost.com/news/story.html?id=1337495 (accessed 201701-26); Gaudreault "The Limits of Restorative Justice" 2005 Paris: Édition Dalloz; Levrant, Cullen, Fulton and Wozniak "Reconsidering Restorative Justice: The Corruption of Benevolence Revisited" 199945 Crime and Delinquency 3-27; Johnstone Restorative Justice: Ideas, Values, Debates (2002).

15 Ibid.

16 Ibid

17 Boisvert "Aboriginal Peoples and Restorative Justice: The Promise of Sentencing Circle" 30 April $2003 \mathrm{http} / / / c i t e s e e r x . i s t . p s u . e d u / v i e w d o c / d o w n l o a d ? d o i=10.1 .1 .122 .2994 \& \mathrm{rep}=$ rep1\& type (accessed 2017-01-05); Bargen, Tomporowski, Binder, and Manon "Reflections on the Past, Present, and Future of Restorative Justice in Canada" 201148 Alberta LR 815 826; Plett "Restorative Justice in Urban Aboriginal Communities" 17 December 1999 http://www.cfcjfcjc.org/sites/default/files/docs/hosted/16177-restorative justice.pdf (accessed 2017-01-05); Lilles "Circle Sentencing: Part of the Restorative Justice Continuum" 9 August 2002 eForum Archive http://www.iirp.edu/eforum-archive/4250-circlesentencing-part-of-the-restorative-justice-continuum (accessed 2017-01-15).

18 Canadian Resource Centre for Victims of Crime "Restorative Justice in Canada: What Victims Should Know" 1 March 2011 https://crcvc.ca/docs/restjust.pdf (accessed 2017-0104).

19 Ibid.

20 McAlinden "The Use of Shame in the Reintegration of Sex Offenders" 200545 British Journal of Criminology 373-394; Daly in Strang and Braithwaite (eds) Restorative Justice and Family Violence; Gxubane "Restorative Justice with Youth Sex Offenders: Issues for Practice" 201426 The Social Work Practitioner - Researcher 241 242; Batley "Restorative Justice in the South African Context" in Maepa (ed) Beyond Retribution: Prospects for Restorative Justice in South Africa (2005) 31; Rugge "Restorative Justice in Cases of Serious Crime" 200510 Research Summary 1-5.

21 McAlinden 200545 British Journal of Criminology; Daly in Strang and Braithwaite (eds) Restorative Justice and Family Violence; Wilson, Huculak and McWhinnie "Restorative Justice Innovations in Canada" 200220 Behavioural Sciences and the Law 363-380; Umbreit Victim Meets the Offender: The Impact of Restorative Justice and Mediation (1994); Umbreit, Bradshaw and Coates "Victims of Severe Violence Meet the Offender: Restorative Justice through Dialogue" 19996 International Review of Victimology 321-343. 
feelings and for the offender to provide answers and explanations for their actions. ${ }^{22}$ Additionally, it also remains far from clear whether $\mathrm{RJ}$ is or should constitute an alternative to retributive justice or it should rather be blended with retributive justice.

As can be garnered from this brief introduction, a number of issues pertaining to the notion of RJ remain controversial. In recent years, these controversies have acquired considerable relevance in countries where $\mathrm{RJ}$ is being invoked in criminal matters, examples of such countries being South Africa and Canada. The purpose of this article, therefore, is to demonstrate how these controversies have played out in the courts of these two countries. The article seeks to show that these courts remain trapped in the tendency to polarise two models of justice - RJ and retributive justice. In addition, these courts still view RJ and retributive justice as alternatives. Last but far from least, many of these courts perceive RJ as a mere a sentencing option, and as a concept that is totally inconsistent with punishment in the form of custodial sentences. The article illustrates that such conceptualisation is problematic, often accounting for RJ's total exclusion from the overall criminal justice process in cases of serious offending. Against this backdrop, an argument is advanced that for RJ to have a meaningful role, especially in cases of serious offending, it should be perceived as a guiding principle that provides a foundation in the overall criminal justice process. To advance the foregoing argument, the article is divided into four sections. Following the present introduction, which constitutes the first section, the second section analyses RJ in the context of South Africa. The third section embarks on the practice of Canadian courts while the fourth section assesses the implications of a RJ for the prosecution of offences committed by children. The fifth section constitutes the conclusion and it basically highlights the salient features of the entire discussion.

\section{RESTORATIVE JUSTICE: THE SOUTH AFRICAN EXPERIENCE}

Throughout African history, traditional African conflict resolution mechanisms embedded values of harmony and restoration. In the specific context of South Africa, commentators submit that RJ is not an entirely new concept. ${ }^{23}$ According to this view, even before apartheid and colonisation, values that have in recent times earned the label of RJ were known and understood by

22 Umbreit Victim Meets the Offender: The Impact of Restorative Justice and Mediation. See also Batley in Maepa (ed) Beyond Retribution: Prospects for Restorative Justice in South Africa 31 who submits as follows: "Applying restorative justice principles and processes in rape and murder cases does not imply minimizing the seriousness and tragedy of such incidents, nor does it suggest that perpetrators should be left off the hook simply because they have apologized. Serious cases present excellent opportunities for victims to feel that they are heard, and for perpetrators to be confronted with the real consequences of their actions. Specific steps can also be taken to ensure that victims are not dealt with insensitively, as restorative justice seeks to promote the respect and dignity off all concerned, especially those who have been hurt."

23 Skelton in Davel (ed) Children's Rights in a Transitional Society 93-94. 
people living in South Africa. In particular, reconciliation, restitution, forgiveness, restoration, peaceful resolution of disputes and harmony were a major feature of African adjudication. Batley makes use of the South African Sotho words: Ngwana phosa dira ga a bolawe meaning, "[i]f a person has erred he does not deserve to be punished too harshly", to locate RJ within the broader framework of African traditional justice. ${ }^{24}$ Over the years, RJ has grown in its stature and impact that it has even received the approval of South Africa's judiciary. There is even an abundance of jurisprudence in which the courts in South Africa have warmly embraced $R J .{ }^{25}$ In some decisions, South African courts have drawn on African indigenous law to justify the application of RJ in criminal cases. ${ }^{26}$ Some of these cases are briefly analysed to assess the manner of conceptualisation adopted and the implication of such conceptualisation for prosecution of serious offenders.

\section{The Maluleke case (2008)}

The Maluleke case is one of the first South African reported cases to apply RJ principles explicitly. The accused was convicted by one of the High Courts of South Africa, of the crime of murder. The crime was in respect of a death caused to a young person who broke into the accused's house with the apparent intent to commit theft. The accused, along with her husband, who died before the trial commenced, caused the death of the deceased by participating actively in assaulting the deceased after he had been apprehended. One of the issues the Court had to resolve pertained to the exact place of RJ in the sentencing of serious offenders. ${ }^{27}$ Early enough in the judgment, the Court acknowledged the burdensome nature of the task of sentencing the offender. Notably, the Court underscored that whereas the

24 Batley 200821 SA Crime Quarterly 34.

25 S v Shilubane 2008 (1) SACR 295 (T) par 297. In this case, Bosielo JA, inter alia, took cognisance of the limits of retributive justice in addressing crime, consequently urging presiding officers to be more "innovative and proactive" in handing down sentences; $S v$ Maluleke 2008 (1) SACR 49 (T) (hereinafter "the Maluleke case"). Here Bertelsmann J categorically pointing out that courts should not be deterred from exploring the feasibility of "exciting and vibrant potential alternative sentences"; Dikoko v Mokhatla 2006 (6) SA 235 (CC) par 33 and 34; the Constitutional Court made interesting and memorable observations on the need for restorative paradigms within the current justice systems. Makgoro $\mathrm{J}$ categorically ruled that: "the law as presently understood and applied does little to encourage repair and reconciliation between parties ... courts should attempt, wherever feasible, to re-establish dignified and respectful relationship between parties ... the goal should be to knit together shattered relationships in the community and to encourage across-the-board respect for the basic norms of human and social inter-dependence"; $S$ V M (Centre for Child Law as Amicus Curiae) 2008 (3) SA 232 (CC) par 62. Here the Constitutional Court affirmed the role of RJ, with Sachs $J$ ruling that RJ recognises the community rather than criminal justice agencies as the prime site of crime control; Le Roux v Dey 2011 (3) SA 274 (CC) par 202. In this case, the Constitutional Court also underscored the role of $\mathrm{RJ}$ in cases involving ruptured personal relationships.

26 S v Maluleke supra. In The Citizen 1978 (Pty) Ltd v McBride (Johannesburg and others, Amici Curiae) 2011 (4) SA 191 (CC) par 217, the Constitutional Court located RJ within the wider framework of African values such as "Ubuntu", with Mogoeng $\mathrm{J}$ ruling that "[a] forgiving and generous spirit, the readiness to embrace and apply restorative justice, as well as a courteous interaction with others, were instilled even in the young ones in the ordinary course of daily discourse".

27 Maluleke case supra par 1-12. 
facts and circumstances of the case presented an opportunity for RJ to be invoked, the offence the accused was guilty of (murder) constituted a very serious crime, warranting the invocation of a severe sentence. ${ }^{28}$ After serious deliberations, the Court ultimately invoked the RJ approach, sentencing the accused to eight years imprisonment, all of which were suspended for a period of three years on condition that the accused apologized to the mother of the deceased and her family within a month after the sentence had been imposed. ${ }^{29}$ As noted, the Court bemoaned the challenge that the sentencing of the offender presented. This opens to question, could perhaps this challenge, partly be attributed to the manner in which RJ was understood and perceived by the Court? Furthermore, could the manner in which the Court viewed and perceived RJ have negative implications for the application of $\mathrm{RJ}$ in cases of serious offending?

A critical reading of the Maluleke case suggests that the decision of the Court to invoke RJ was anchored on four premises. These premises appear to have had major implications for how the Court perceived, understood and applied RJ. Firstly, RJ was fronted as an approach that excludes punishment in forms such as imprisonment. ${ }^{30}$ Secondly, and with particular regard to the apparent case, RJ, when compared to the conventional system of justice, constituted a better approach. ${ }^{31}$ Thirdly, RJ constituted an alternative to the conventional system of justice ${ }^{32}$ and fourthly, RJ was reduced to a mere sentencing option. ${ }^{33}$ Although these premises are not explicitly mentioned by the Court, they can vaguely be deduced from the various rulings made. The premise that RJ, when compared to the conventional system of justice, is the better approach could imprecisely be inferred from a number of rulings, one is a notable one:

"[restorative justice is] a new approach to dealing with crimes, victims and offenders. It emphasises the need for reparation, healing and rehabilitation rather than harsher sentences, longer terms of imprisonment, adding to overcrowding in jails and creating greater risks of recidivism.

It is apparent from the above ruling that in mapping out the parameters of $\mathrm{RJ}$, already, the Court was comparing RJ to conventional sentencing approaches, with RJ seemingly being considered the better approach on account of its potential to address the failings of the conventional system. While at first glance, such a narrative merely seeks to justify the invocation of RJ, on closer scrutiny, it appears to create some sort of dichotomy between two systems of justice, namely, RJ and retributive justice, the former being the better approach. This dichotomy turns out to be a golden thread running through the decision of the Court, with the Court, at some

\footnotetext{
Maluleke case supra par 12.

Maluleke case supra par 22.

Maluleke case supra par 26 and 29.

Ibid.

Ibid.

Maluleke case supra par 29. Here the Court endorses the view that RJ constitutes a shift, suggesting a new and alternative to the conventional approach, in this case retributive justice. See also par 35 in which the Court explicitly refers to it as an alternative.

34 Maluleke case supra par 26.
} 
point, ruling that "restorative justice shifts the focus of the criminal process from retribution to healing..."35 The Court remains true to this dichotomy, underscoring that $\mathrm{RJ}$ has the potential to provide alternatives to values that embed the conventional system of justice including imprisonment. To further buttress this point, the Court draws on the practice in other countries including Canada, New Zealand and Australia where RJ has been invoked as an alternative to imprisonment, with the Court concluding: "there appears to be little reason why similar results could not be achieved in South Africa." ${ }^{36}$ The foregoing rulings, unquestionably, also bring sharply into focus another premise highlighted - that RJ constitutes an alternative to conventional criminal justice approaches.

Equally salient in the Maluleke decision are the various rulings of the Court suggesting that RJ excludes punishment or custodial sentences in forms such as imprisonment. As already alluded to, the Maluleke Court sentenced the accused to eight years imprisonment, all of which were suspended for a period of three years. ${ }^{37}$ In the ordinary course of events, the accused in the Maluleke case was supposed to be sentenced to some form of the custodial sentence given the seriousness of the crime she committed (murder). Earlier in the judgment, the Court had ruled, inter alia, that RJ constitutes a new approach, which shifts the focus away from imprisonment. ${ }^{38}$ With a perspective such as the foregoing, it would follow that if the RJ option is considered, imprisonment would under no circumstance feature. It would then appear that if imprisonment were to be invoked, it would contravene the concept of RJ, which the Court had categorically perceived as excluding custodial sentences. Moreover, in anchoring the concept of $\mathrm{RJ}$ in the nature of the sentence handed down by the court, ${ }^{39}$ the Court implicitly reduced RJ to a mere sentencing option, effectively negating the many other roles that RJ can play including in the pre-sentencing stages.

It is, perhaps, such oversimplification of the notion of $\mathrm{RJ}$ that is the root cause of the challenge that judges face in invoking $\mathrm{RJ}$ in cases of serious offending. With RJ perceived as excluding punishment, as merely a sentencing option and an approach that constitutes an alternative to conventional sentencing, a sentencing judge is inevitably trapped into the scenario that one would best describe as the "either-or" dilemma. Essentially, the fact that RJ and conventional criminal justice mechanisms are perceived as alternatives or rather as total opposites, would suggest that the application of one necessarily excludes the application of the other and as such, $\mathrm{RJ}$ and conventional goals of sentencing such as retribution cannot co-exist. Arguably, if sentencing judges were to view RJ as a guiding principle that provides a foundation for the entire criminal justice process rather than a mere alternative to conventional criminal justice approaches,

Maluleke case supra par 29

Maluleke case supra par 30.

Maluleke case supra par 22.

Maluleke case supra par 29 and 35.

See Maluleke case supra par 26 in which the Court endorses RJ as "a new approach to dealing with crimes, victims and offenders." 
they would have spared themselves the dilemma of having to choose one approach over the other.

One of the ways the above challenges can be overcome is through an appreciation of the parameters of the concept of restorative justice, specifically, what it is and what it is not. Worthy to note, however, venturing into understanding $\mathrm{RJ}$ is tantamount to the proverbial opening of a can of worms. Judicial officers will be confronted with a number of controversial issues in so far as this notion is concerned, including whether or not RJ necessarily excludes punishment, whether or not it is a better approach to justice, whether or not it is an alternative or complementary to conventional justice and whether it should constitute merely a sentencing option. Ideally, judges would have to exercise their discretion to decide, from which vantage point RJ should be viewed. It is submitted that the standpoint from which RJ is invoked profoundly impacts on whether or not it makes a meaningful contribution to cases of serious offending. It is further contended that if $\mathrm{RJ}$ is to make a meaningful contribution in the sentencing of serious offenders, it should be viewed from a standpoint of a guiding principle and as such, not necessarily excluding conventional approaches such as imprisonment. This would relieve sentencing judges of the burden of pitting one approach against the other, a practice that pushes judges into preferring one approach over the other.

\section{The Thabethe case (2011)}

In the Thabethe case, the accused was found guilty of the rape of a daughter of his life companion. The rape occurred when the complainant was 15 years of age. A day after the sexual intercourse with the complainant, the accused reported the sexual intercourse to the police and voluntarily handed himself over. At the time of the rape, the accused had for some years been staying with the victim's mother. For some time before the rape, the accused had been providing for the family consisting of himself, the victim's mother, the victim, the victim's younger sister and a boy that was born of the union between the accused and the victim's mother prior to the offence. Before the trial was concluded, another son was born to the victim's mother. The accused was the father of this child. The accused pled guilty and accordingly convicted.

During sentencing at the High Court, the complainant, a child sexual abuse victim, stated that she was still deeply hurt by the fact that she had been subjected to a violent offence by a man she had trusted. On the other hand, she pleaded that the accused should not be sent to jail because the entire family, including herself, depended upon his income. One of her siblings was chronically ill and the accused provided for her medical treatment. She herself was still attending school and needed his support to continue her education. The court made known to the victim that she had an inalienable right to convey her own emotions, feelings and convictions, her own view of a suitable sentence for the accused, and that the court was obliged to pay attention to her wishes. The complainant reiterated that she regarded it as being in the best interests of her family, herself and her further schooling that the accused should not be incarcerated. The Court found that 
the facts of the case presented an opportunity in which "restorative justice could be applied in full measure". ${ }^{40}$ The court accordingly launched a victim/offender programme under the guidance of the local probation officer and supervised by the Restorative Justice Centre in Pretoria (South Africa). The court was of the view that the programme was essential to determine whether the wishes expressed by the complainant regarding the sentence of the accused were indeed genuine and had a realistic prospect of being realised for the benefit of every individual affected by the crime.

During the programme, a meeting was arranged between the offender and the victim, during which the accused formally apologized for his misdeed, which apology was accepted. All the discussions were recorded by the probation officer. When an appropriate sentence for the accused was discussed, the record indicated that the victim was satisfied that the offender used the programme effectively to apologise for what he did to her. She further indicated that she would be satisfied with any sentence that the court imposed to the offender, although her wish was not to see the offender being sentenced to imprisonment. After assessing the outcome of the RJ programme, the court found that there were a number of substantial and compelling circumstances that individually and collectively justified the imposition of a lesser sentence than the minimum sentence of life imprisonment prescribed by Act 105 of 1997 in Part 1 of Schedule 2 thereto read with section 51 of the Act. ${ }^{41}$ Against this backdrop, Bertelsmann $\mathrm{J}$, having found the case appropriate for the application of RJ, sentenced the accused to ten years imprisonment, all of which were suspended for five years, subject to certain conditions. ${ }^{42}$ Bertelsmann was of the opinion that in the appropriate circumstances, RJ can be suitable in matters of a grave nature such as the one at hand. ${ }^{43}$

The Director of Public Prosecutions opposed the decision of the High Court on sentence in the Supreme Court of Appeal. The Supreme Court of Appeal ultimately overturned the sentence handed down by the High Court. Of importance to this discussion, the crux of the matter is not whether or not the Supreme Court of Appeal should have overturned the High Court

$40 \quad S v$ Thabethe 2009 (2) SACR 62 (T) par 36.

41 The substantial and compelling circumstances were as follows:

- The accused pleaded guilty and was genuinely remorseful.

- The accused remained involved in the family of which the victim was part of.

- The accused continued to support the family including the victim through the period from commission of the offence to the end of the trial.

- The accused maintained his employment and fulfilled his obligations towards the family throughout the trial.

- If the accused were to be sentenced to imprisonment, he would lose his employment and income and the family would lose its only source of support. This would most likely lead to the loss of the family home.

- The accused did not present a threat to the community and was highly unlikely to reoffend.

- The family was entirely dependent upon the accused.

- The victim was fully aware of this fact and concluded that it would not be in the family's interest that the accused be incarcerated. Thabethe case par 35.

42 Thabethe case supra par 37.

43 Thabethe case supra par 39. 
decision, but rather, the standpoint of which the Court and perhaps, the parties too, understood and perceived RJ, and the implications of such a perspective for RJ in cases of serious offending. Notably, the appellant was of the opinion that given the nature and gravity of the offence, and the fact that the legislature prescribed life imprisonment as the minimum sentence for this offence, the RJ sentence imposed by the High Court was inappropriate. The appellant contended further that the fact that the respondent stood in a father-daughter relationship, which invariably involved trust, made this offence even more serious. Essentially, the inappropriateness of the RJ sentence, in the appellant's view, was based on the fact that the sentence handed down was not custodial and as such, failed to reflect the seriousness of the offence in issue. Put another way, the appellant's argument was anchored in the fact that an RJ sentence excludes punishment by way of imprisonment and as such, inappropriate in a case of serious offending such as the apparent one.

The Supreme Court of Appeal ultimately handed down its judgment, with Bosielo JA, cautioning "against the use of RJ as a sentence for serious offences". ${ }^{44}$ Bosielo JA was of the opinion that although the facts of the case presented compelling circumstances, a sentence "based on restorative justice" was inappropriate. ${ }^{45}$ The court ruled further that since in terms of sections 51(5) (a) and section 294(4) of the Criminal Procedure Act, the sentence could not be suspended, the High Court sentence had to be set aside. In the result, the Supreme Court of Appeal upheld the appeal, consequently replacing the High Court sentence with 10 years' imprisonment. ${ }^{46}$ Here again, the inappropriateness of the RJ sentence appears to be anchored on the premise that RJ generally cannot co-exist alongside punishment by way of imprisonment. Implicitly, the Court would seem to reduce $\mathrm{RJ}$ to an approach that excludes custodial sentences.

The Supreme Court of Appeal also appears to proceed from the standpoint that $\mathrm{RJ}$ is an alternative to conventional sentencing, a dichotomy that, as consistently alluded to, often entraps sentencing judges into an "either-or" approach. Bosielo JA observes:

"I have no doubt about the advantages of restorative justice as a viable alternative sentencing option provided it is applied in appropriate cases.

Without attempting to lay down a general rule I feel obliged to caution seriously against the use of restorative justice as a sentence for serious offences which evoke profound feelings of outrage and revulsion amongst law-abiding and right-thinking members of society."

The rulings of the Court and the arguments advanced by the appellant, made it apparent that RJ was conceptualised as an alternative, and that it does not encompass punishment in the form of imprisonment. Equally apparent is the fact that $\mathrm{RJ}$ was reduced to a mere sentencing option. An approach that reduces $\mathrm{RJ}$ to a mere sentencing option; ties the

44 Director of Public Prosecution, North Gauteng v Thabethe 2011(2) SACR 567 (SCA) par 20 (Thabethe Appeal).

45 Thabethe Appeal par 22.

46 Thabethe Appeal par 31.

47 Thabethe Appeal par 20. 
inappropriateness of the $\mathrm{RJ}$ sentence to its failure to encompass imprisonment and one that perceives $\mathrm{RJ}$ as an alternative; implicitly suggests that RJ cannot rest comfortably alongside retributive justice because the latter form of justice may often require that custodial sentences be handed down, specifically, in cases of serious offending. In fact, the appellant's argument to the effect that the RJ sentence was inappropriate ${ }^{48}$ seemed to implicitly suggest that RJ cannot co-exist alongside a sentence that encompasses imprisonment, a perception that is somewhat problematic. Worthy to emphasise, the issue is not so much, whether or not the Supreme Court of Appeal replaced the sentence with a 10-year sentence but rather, the oversimplification of the notion of $\mathrm{RJ}$ so much so that its overall contribution to the entire criminal justice process was obscured. Reducing the notion of RJ to a mere sentencing option had the effect of negating the numerous roles that $\mathrm{RJ}$ can play in cases of serious offending/offences such as empowerment of the victim through participation, the involvement of the community, etc. It is against this backdrop that the argument is consistently made that the manner in which RJ is conceptualized, particularly in cases of serious offending/offences, should be rethought. It is more than a sentencing option and this very small facet should not necessarily inform decisions on whether or not RJ should have a role in cases of serious offending/ offences.

\section{The Seedat case $(2016)^{49}$}

The Seedat case presents yet another unique set of facts on how the notion of RJ played out. The facts of the case were that Seedat, the appellant, aged 60 years at the time, was charged with the crime of rape in the SchweizerReneke Regional Court. The facts were that he allegedly raped JM, an old woman aged 57 years by inserting his penis into her vagina. Before proceeding further, this case entails a number of issues warranting of discussion. However, the present discussion restricts itself to those facts and issues, which touch upon the concept of RJ. That said, the Regional Court received a range of submissions, one notable one being that of a clinical psychology who stated that the complainant had, inter alia, informed her that she wished that the Court would impose a community-based sentence on the appellant and also, order for financial compensation to be paid by the appellant to her for the trauma she had suffered. ${ }^{50}$ Specifically, she requested the psychologist to convey to the Court her wishes as follows:

a) That the appellant pay her R 500,000,

b) that the appellant purchases her a Toyota Motor car,

c) that if possible, the appellant pay her an amount of R 100,000 as compensation in light of her dire financial situation at the time and

48 The minimum sentence for this nature of the offence was life imprisonment.

49 Seedat v S (731/2015) [2016] ZASCA 153 (hereinafter "the Seedat case").

50 Seedat case supra par 12 and 13. 
d) that she gets intervention from social workers to deal with an alcohol problem she had suffered from for quite some time..$^{51}$

The State, however, did not support the complainants' request, arguing that a lengthy term of imprisonment was the most appropriate sentence for a crime as serious as the apparent one. ${ }^{52}$ Despite the submissions made by the clinical psychologist and as confirmed by the complainant herself, the Regional Court, having convicted the appellant, deemed it fit to hand down a sentence of 7 years' imprisonment. ${ }^{53}$

The appellant, dissatisfied with the conviction and sentence handed down, appealed against the decision of the Regional Court. The High Court ${ }^{54}$ dismissed the appeal on conviction but set aside the sentence handed down, substituting it as follows:

a) That the sentence of the accused be suspended for a period of five years on condition that,

b) The accused pays the complainant a total amount of $R 100,000 .{ }^{55}$

The DPP sought leave to appeal the sentence of the High Court in the Supreme Court of Appeal on the basis that the sentence was incompetent and invalid, which leave was granted. ${ }^{56}$ Again, the discussion here will not delve into the comprehensive subject of minimum sentences. ${ }^{57}$ This exclusion is not to suggest that this issue is irrelevant, however, the points that need to be made can be advanced without venturing into this detailed discussion. For this purpose, the focus here is placed on the sentiments of the Supreme Court of Appeal on the concept of RJ in cases of serious offending. On this latter issue, the Supreme Court of Appeal, inter alia, made explicitly its rejection of RJ in this case, because in the Court's view, it was a very serious offence. ${ }^{58}$ The Court endorsed the ruling of the Court in the Thabethe case earlier discussed in this article, with the Seedat Court reiterating categorically that although RJ has several advantages, "it is not a viable alternative sentencing option." ${ }^{59}$ In the Court's view, it was fair that the victim's voice be heard since it is "the victim who bears the real brunt of the offence committed against him or her." ${ }^{\prime 60}$ The Court, however, emphasised that the fact that rape was a very serious scourge in society it warranted a severe sentence so that a message is sent out to the public about the seriousness of this crime. ${ }^{61}$ The Court was also particularly concerned that "the public would justifiably be alarmed if courts tended to impose a suspended sentence coupled with monetary compensation for rape" for such

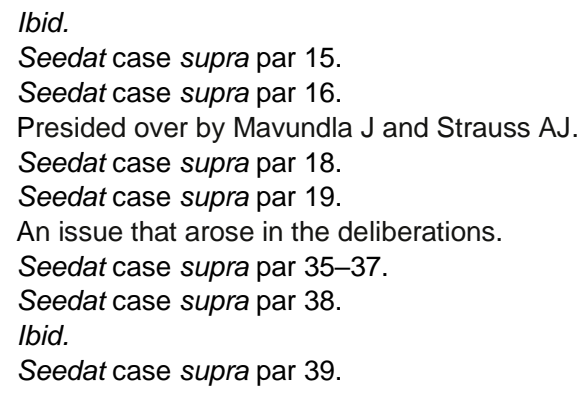


a serious crime. ${ }^{62}$ The Court accordingly substituted the suspended sentence, and the compensation order thereof, with a four-year sentence. ${ }^{63}$

Much can be said about this case. It is, however apparent that the approach adopted by the Seedat court is very much similar to that of the Thabethe court. For this purpose, to avoid repetition in terms of analysis, a few salient points are worthy of mention. Notably, one can garner that the Seedat case confirms the challenges consistently underscored thus far, namely: the tendency to equate $\mathrm{RJ}$ to an approach that necessarily excludes punishment, to reduce $\mathrm{RJ}$ to merely a sentencing option and to perceive RJ as an alternative to retributive justice and as such, incapable of resting comfortably alongside retributive justice. One is forced to pause and to question, even supposing the four-year sentence was handed down, did it necessarily preclude the court from adding a touch of RJ by acknowledging the voice of the victim, which voice made it apparent that the victim wanted some form of compensation for the harm she suffered? There was certainly room for the four-year custodial sentence to co-exist alongside an order for compensation, yet, both the High Court and Supreme Court of Appeal chose to perceive the four-year sentence and $\mathrm{RJ}$ as alternatives, with the application of one necessarily excluding the application of the other.

Moreover, it is interesting to note that the appellant had already expressed willingness to pay compensation to the victim but this reality seemed inconsequential since RJ goals such as compensation had already been conceptualized as alternatives to notions such as custodial sentences. ${ }^{64}$ Arguably handing down the four-year custodial sentence coupled with an order for compensation, in whatever form such compensation took, would have ensured that a balance is struck between the goals of $\mathrm{RJ}$ on the one hand and the goals of conventional sentencing such as deterrence and retribution. Such a balance would arguably not have made rape less of a serious crime, neither would it have silenced the voice of the victim, who as the record indicates stated: "[even after the imprisonment] the appellant would be freed very soon, come back and laugh and nothing would have changed on [my] part." ${ }^{65}$ Cases such as the Seedat case reinforce the argument that courts need to strike a balance between retributive justice and $\mathrm{RJ}$ in cases of serious offending.

The viability of courts to strike such a balance is not farfetched, to say the least. The New Zealand case of $R v$ Clotworthy $^{66}$ constitutes a prime $^{2}$ example of how courts can strike a balance between the goals of retribution on the one hand and the goals of RJ on the other. In this case, the accused, a young man was charged with the offence of wounding with intent to cause grievous bodily harm. The facts of the case were that the accused, a young man, while intoxicated with alcohol, stabbed another man (the victim). As the position was in the Thabethe case, the sentencing judge referred the matter

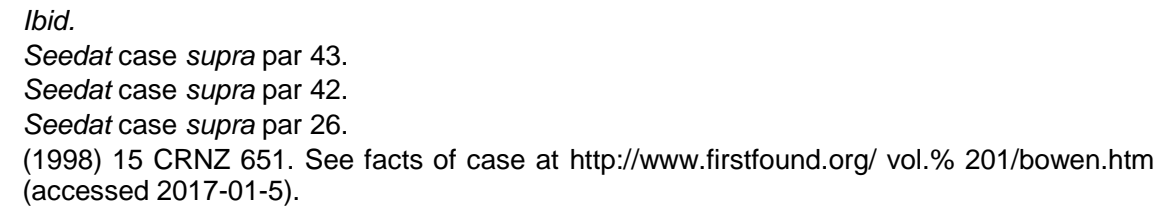


to a restorative justice conference. ${ }^{67}$ The victim of this crime saw no sense in the accused being imprisoned. He, however, requested, and upon agreement with the accused, that the accused pays him compensation by way of an amount of money to cater for the surgery he needed to undergo with respect to the scarring that resulted from the stabbing. ${ }^{68}$ In light of the outcomes of the RJ conference, the sentencing judge handed down a twoyear custodial sentence, all of it suspended, on condition that the accused paid the compensation amount to the victim. ${ }^{69}$ The Court of Appeal, however, thought otherwise, replacing the sentence handed down by the court a quo with a three-year sentence, none of which was suspended. ${ }^{70}$ The Court of Appeal, however, made an interesting ruling with regard to RJ. Without denouncing the role of RJ in cases of serious offending, the Court observed that the goals of RJ should be balanced with the notions of deterrence, denunciation and retribution, ruling categorically that:

"we would not want this judgement to be seen as expressing any general opposition to the concept of restorative justice [...]. Which aspect will predominate depend on assessment of whether the balance should lie in individual cases. Even if the balance is found, as in this case, to lie in favour of a [a custodial sentence], the restorative justice application have, as here, a significant impact on the length of the term of imprisonment which the Court is directed to impose. They find their place in the ultimate outcome that way."

Most notably, the Court considered the appropriate starting point for the case was five years imprisonment. However, having balanced the goals of $\mathrm{RJ}$ with the goals of retributive justice, the custodial sentence was reduced to three years in conjunction with 5,000 New Zealand dollars as reparation to the victim of the crime. ${ }^{72}$ A significant difference between the Seedat case and the Clotworthy case is that the Seedat case made no mention of the role that RJ could play in the overall criminal justice process, rejecting it in its entirety in so far as cases of serious offending/offences are concerned. In the Clotworthy case, however, despite the scale tipping in favour of a custodial sentence, the Court did not rule out the role that RJ still played in the overall criminal justice process, including, informing the overall length of the sentence ultimately handed down by the Court. Considered together, the manner in which RJ was conceptualized in the Seedat case had major implications for how it played out in the overall decisions of the courts. All courts in the Seedat case, including the High Court, which made an order for compensation, perceived RJ, by way of compensation, as an approach that could not co-exist alongside custodial sentences. It is apparent that the application of a custodial sentence automatically excluded the application of RJ by way of compensation. Essentially, one approach had to be applied to the exclusion of the other since they constituted alternatives. Such a conceptualization set RJ up for exclusion in the overall prosecution of cases of serious offending/offences, an approach that criminal justice professionals

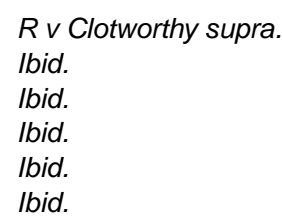


need to be cautious of and arguably avoid whenever RJ features in cases of serious offending.

\section{3 \\ RESTORATIVE JUSTICE: THE CANADIAN EXPERIENCE}

Canada played a key role in the adoption of the Basic principles on the use of restorative justice programmes in criminal matters by the United Nations Economic and Social Council in 2002. ${ }^{73} \mathrm{RJ}$ has featured prominently in criminal matters in Canada's justice system over the years and Canada "continues to share its experiences and expertise at the international level". ${ }^{74}$ Not surprisingly, the courts in South Africa have on occasion drawn insight from Canada's practice. ${ }^{75}$ Essentially, the notion of RJ is not novel to Canada's criminal justice system, with one of the areas in which the application of RJ has gained prominence being the prosecution of offences committed by aboriginal people. The mention of offending by aboriginal people brings sharply into focus section 718 (2) (e) of the Canadian Criminal Code. The foregoing section reads: "all available sanctions other than imprisonment that are reasonable in the circumstances should be considered for all offenders, with particular attention to the circumstances of aboriginal offenders." The Supreme Court of Canada has ruled that section $718(2)$ (e) of the Criminal Code is "remedial in nature and is designed to ameliorate the overrepresentation of the aboriginal people in prisons, and to encourage sentencing judges to have recourse to a restorative approach to sentencing". ${ }^{76}$ Essentially, it alters "the method of analysis which sentencing judges must use in determining a fit sentence for aboriginal offenders". ${ }^{\text {. }}$ Pertinent to note, section 718 does not explicitly make mention of RJ with regard to aboriginal offenders. ${ }^{78}$ However, the use of RJ flows from the duties of a sentencing court as set out in some of the decisions handed down by the Supreme Court of Canada. ${ }^{79}$ Some cases are now briefly examined to assess how Canadian courts have fared.

\section{The Gladue case (1999)}

The case of Gladue gave meaningful content to section 718(2)(e) of the Canadian Criminal Code, which, as consistently alluded to mandates the courts to consider all available sanctions other than imprisonment for all offenders, with particular attention to aboriginal offenders. In the Gladue case, the accused (Gladue) pled guilty to manslaughter, having killed her husband (Beaver). In determining the appropriate sentence, the trial judge took into consideration a number of mitigating factors including the fact that

73 Public Safety Canada "Restorative Justice" 2015 https://www.publicsafety.gc.ca/cnt /cntrng$\mathrm{crm} / \mathrm{crrctns} /$ rstrtv-jstc-eng.aspx?wbdisable=true (accessed 2017-01-03).

74 Ibid.

75 Maluleke case supra par 28, 30 and 39.

$R v$ Gladue (1999) 1 SCR 688 par 690.

$R v$ Gladue supra par 690.

$R v$ Elliott 2016 ONCJ 35 (CanLII) par 13.

See eg, $R v$ Gladue supra and $R v$ Elliot supra par 13. 
the accused was a young mother, she had no previous criminal record and that she was provoked by the victim. ${ }^{80}$ The trial judge also took into account a number of aggravating factors, which in the Court's view made the offence committed a serious one. The Court ruled, inter alia, that Gladue had the intent to cause the death of the deceased. ${ }^{81}$ Against this backdrop, the trial judge was of the view that the principles of denunciation and general deterrence were very critical in informing the sentence handed down. ${ }^{82}$ As such, it was not appropriate, the Court emphasized, to suspend the sentence or to impose a conditional sentence. ${ }^{.3}$ In the trial Judge's view, although Gladue was of aboriginal origin, the offence in issue was very serious so much so that three years' imprisonment was appropriate.

A critical analysis of the Gladue case demonstrates that the arguments advanced by the parties, specifically the appellant, were based on the premise that RJ was tantamount to an approach that excludes imprisonment, which it constitutes an alternative to conventional sentencing and that it is merely a sentencing option. Notably, in appealing against the decision of the trial court in the Supreme Court of Appeal of Canada, the appellant (Gladue) contended, inter alia, that "the trial judge failed to give appropriate consideration to her circumstances as an aboriginal offender" and as a consequence, arrived at a sentence that was not appropriate. ${ }^{84}$ Put another way, in the appellant's view, giving appropriate consideration to the circumstances of the aboriginal offender meant invoking a RJ approach. RJ, in the appellant's view, it does appear, meant handing down a non-custodial sentence. It is arguably against this backdrop that the appellant took the view that the sentence handed down was inappropriate. Implicitly, one can garner that even before the Court ventured into an analysis of the arguments advanced by the appellant, the appellant had already, albeit implicitly, set the pace as to how the notion of RJ should be conceptualized - an approach that excludes punishment and one that merely finds relevance at the sentencing level. It would remain to be seen whether or not the Supreme Court, in analyzing the arguments advanced by the appellant, adopts a different form of conceptualization.

To delve straight to the point, Gladue's appeal was dismissed by the Supreme Court of Appeal. The Supreme Court of Appeal made a number of interesting rulings on the implications of section 718(2) (e) for serious offenders. All these rulings are worthy of discussion, however, the focus is placed on the rulings that touch on the subject of $\mathrm{RJ}$ and how this notion was conceptualized. Amongst others, the Court ruled that section 718(2) (e) does not imply that:

"as a general practice, aboriginal offenders must always be sentenced in a manner which gives greatest weight to tones of the principles of restorative justice, and less weight to goals such as deterrence, denunciation, and separation [...] Clearly there are some offences and some serious offenders

\footnotetext{
$R v$ Gladue supra par 689.

$R v$ Gladue supra par 700-701.

$R v$ Gladue supra par 701

Ibid.

Ibid.
} 
for which and for whom separation, denunciation and deterrence are fundamentally relevant [emphasis added].

A number of issues can be garnered from the above ruling. Firstly, that separation, denunciation and deterrence are fundamentally relevant in cases of serious offending. Secondly, there is an implicit assumption that these goals are best advanced by custodial sentences in the form of imprisonment. Thirdly, that RJ cannot be relied on to advance these goals because of another implicit assumption that RJ is incompatible with punishment in the form of custodial sentences. By explicitly rejecting a RJ approach in a case that the Court deemed very seriously, the Court implicitly reinforced the view that RJ is an approach that excludes punishment in forms such as imprisonment. Because RJ was viewed as such, it could not be invoked in a case as serious as the apparent one because it would defeat the goals of deterrence, separation and denunciation. To invoke RJ, it seems apparent from the ruling of the court, would be to make it an alternative to a sentencing approach that places emphasis on deterrence, separation and denunciation as goals of sentencing serious offenders. It could, therefore, not co-exist alongside such a conventional approach and as the Court itself ruled, "there are some offences and some serious offenders for which and for whom separation, denunciation and deterrence are fundamentally relevant." In such cases, the Court seems to suggest, RJ loses its grip and conventional methods of sentencing take centre stage.

Considered together, the manner in which RJ was viewed automatically set RJ up for exclusion in a case of serious offending. Perceiving it as necessarily excluding punishment suggested that it could not co-exist alongside the conventional system of sentencing, which often places emphasis on punishment in the form of imprisonment in cases of serious offending. It automatically became an alternative that had to be set aside for the ends of deterrence, separation and denunciation to be met. This placed the Court in a position that is consistently referred to in this paper as an "either/or" approach - an approach that often places judicial officers in a position of having to choose between RJ and conventional methods of sentencing serious offenders. Worthy to note also, the Gladue Court does appear to have reduced RJ to a sentencing goal. In ruling that for serious offences, RJ loses its grip for the ends of deterrence, denunciation and separation to be met, the Court, again implicitly, negated the role RJ could, perhaps, have played or even played in other stages of the criminal justice process, amongst which were victim empowerment/voice, community participation etcetera.

Of importance for this discussion also is the fact that this dilemma does not start in Court, rather, it finds its roots in the manner in which RJ was understood and conceptualized by the parties themselves. The end result of the conceptualization of $\mathrm{RJ}$ by the parties appears to have impacted on whether or not RJ finally plays a role in cases of serious offending. Notably, in all the cases analyzed thus far, RJ was often viewed as an approach that totally frowned upon punishment and as such, invoking it suggested that the

$85 \quad R v$ Gladue supra par 729. 
goals of imprisonment such as deterrence, denunciation and separation could not be advanced. Such a conceptualization, as can be garnered from the preceding cases, led to the overall rejection of RJ, thus negating even the other tenets of RJ, which have little or nothing to do with the concept of sentencing. Some notable ones could be restitution, victim compensation, victim participation etc. Certainly imposing a custodial sentence does not bar the sentencing judge from invoking some tenets that can advance restoration justice such as restitution and compensation. Arguably, instead of a blanket rejection of $\mathrm{RJ}$ as a notion ill-suited for cases of serious offending, sentencing judges should strike some form of a balance that ensures that the proverbial bathwater is not poured out with the baby.

\section{The Pauchay case (2008)}

In the Pauchay case, the accused (Pauchay), of aboriginal origin, was convicted of the crime causing death by criminal negligence. Pauchay had two daughters aged two and a half years and five years respectively. On 28 January 2007, Pauchay who was reportedly worried that one of his daughters was not well, sought to seek help for the said daughter during which he took both of his daughters in the freezing winter air dressed only in T-shirts. Both girls were found dead as a result of the cold. As a background, Pauchay, had, a few hours prior to the alleged incident been engaged in the excessive consumption of alcohol and was heavily drunk at the time of this incident. Pauchay's deliberate excessive consumption of alcohol made him incapable of protecting his children. He pled guilty and was accordingly convicted. ${ }^{86}$ In terms of the sentence to be handed down, Pauchay requested for a sentencing circle to be held for purposes of determining an appropriate sentence, which request was granted by the Provincial Court judge. ${ }^{87}$

The members of the sentencing circle, including elders of the Yellow Quill Community from where Pauchay hailed, recommended, inter alia, that Pauchay performs community service in the Yellow Quill Community as opposed to being incarcerated. ${ }^{88}$ One of the issues the Court had to resolve was whether or not, based on section 718(2) (e) (which mandated courts to consider all available sanctions other than imprisonment for offenders, with particular attention to aboriginal offenders), the accused should be given a non-custodial sentence resulting from the recommendations made by members of the sentencing circle. Both the Crown and the Defence made submission as to the appropriateness of having a sentencing circle for this nature of the crime.

According to the Crown, given the seriousness of the offence, Pauchay needed to be incarcerated. ${ }^{89}$ The Crown stressed that "the sentence must be one that protects the public and is fit and just in the circumstances" ${ }^{90}$ While

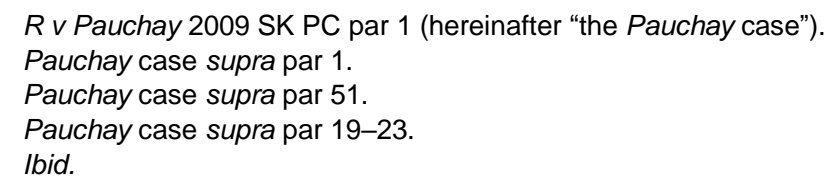


the Crown acknowledged the need for reformation and rehabilitation of Pauchay, it was also of the opinion that denunciation and deterrence were considerations that are paramount in a crime as serious as negligently causing the death of children. ${ }^{91}$ In the Crown's view, given the extremely serious nature of the offence in issue, a custodial sentence, ranging between two and a half years and five years was the only realistic sentence.

Much can be deduced from the arguments advanced by the Crown. Most notably, however, the Crown reinforces the viewpoint that in cases of serious offending, some form of punishment is warranted, in this case, a custodial form of a sentence. The said custodial sentence is with a view to advancing goals, which the Crown refers to as denunciation and deterrence. From such a perspective, it would follow that any approaches that exclude the handing down of a custodial sentence would most probably not suffice because to invoke them would be to defeat the goals of denunciation and deterrence. The manner in which RJ is conceptualised by the defence would therefore have major implications for RJ's co-existence alongside the conventional method of sentencing. It would remain to be seen what the nature of the arguments advanced by the defence left room for such co-existence.

Notably, the defence, emphasized, inter alia, that the Court should take cognizance of the principles of sentencing, which underscore that incarceration should be seen as a last resort, especially for aboriginal offenders. ${ }^{93}$ The Defence also drew the attention of the Court to a number of mitigating factors including Pauchay's guilty plea, his former primary caregiving role to his two daughters, his preparedness to receive treatment for his alcohol problem and the potential of the sentencing circle recommendations to advance the ideals of RJ. ${ }^{94}$ Pauchay also addressed the Court, expressing his regret in causing the death of the victims and acknowledging that he had an alcohol problem. ${ }^{95}$ Pauchay also questioned the practicality of a custodial sentence addressing his circumstances as an offender.

It is apparent that the arguments advanced by the defence go totally contrary to the arguments that the Crown advances (for obvious reasons of course). The defence vouches for a purely non-custodial sentence in a case; that as consistently alluded to, is a serious one. The challenge with the line of argument advanced by the defence is that in vouching for a purely noncustodial sentence for a case of serious offending, a dichotomy is automatically created in which case the Court has to choose between two systems of justice. ${ }^{96}$ Indisputably, one can glean that the dichotomy between systems of justice or rather the manner in which RJ or systems of justice are

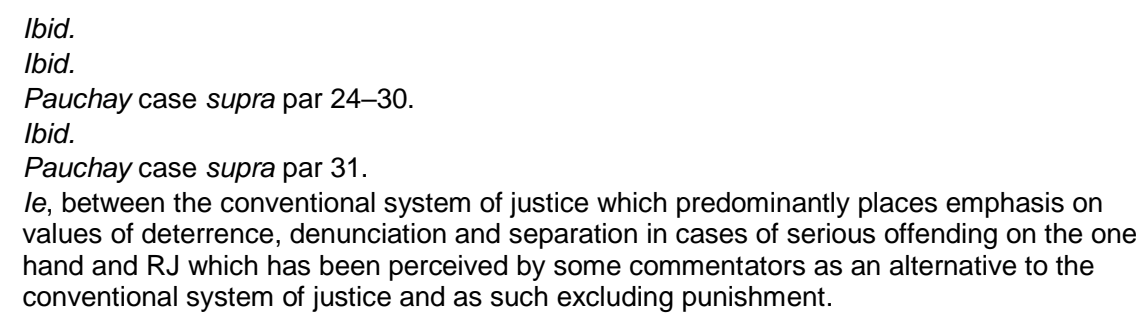

$l e$, between the conventional system of justice which predominantly places emphasis on values of deterrence, denunciation and separation in cases of serious offending on the one hand and RJ which has been perceived by some commentators as an alternative to the conventional system of justice and as such excluding punishment. 
conceptualized can be traced back to the nature of arguments made by the parties to this case. It would remain to be seen how the Court would deal with this dichotomy.

Evident in the ruling of the Court on this issue is the precarious position that the Court finds itself. The Court had to be alive to the goals of RJ on the one hand and retributive justice on the other. Yet, because it does appear that these two systems of justice had already been conceptualized by the parties as alternatives, and as such, incapable of co-existing, the Court had to choose one system of justice over the other. Notably, the Court, amongst others, took cognizance of the fact that there were underlying problems in Pauchay's life that needed to be addressed. ${ }^{97}$ In particular, that his alcohol problem was a major contributing factor to his criminal record. ${ }^{98}$ The Court also took note of Pauchay's personal circumstances including his disadvantaged background, exposure to substance abuse, and poverty. ${ }^{99}$ It also considered a number of mitigating factors including Pauchay's remorsefulness and guilty plea. ${ }^{100}$ The reports on record also indicated that the community of Yellow Quill was prepared to support Pauchay in serving the community service and dealing with the underlying causes of his criminal conduct. ${ }^{101}$ In the Court's view, however, "the fact still [remained] that two defenseless young victims lost their lives as a direct consequence of his reckless behaviour". ${ }^{102}$ The Court accordingly handed down a sentence of three years imprisonment. One ruling of the Court is particularly worthy of emphasis. The Presiding Judge (Morgan J) ruled, inter alia, that:

"the principle of denunciation and the need to foster respect for the judicial system, mandates a significant response. Although I appreciate the input of the community of Yellow Quill, as expressed through the process of the Sentencing Circle, I cannot agree with the recommendations of that circle. Nor do I have the jurisdiction, even were I so inclined, to construct a sentence that would place Mr. Pauchay under community control in the manner suggested; the maximum duration of a probation order is three years."

As a starting point, sentencing circles constitute one of the mechanisms through which the goals of RJ can be anchored and advanced. Put another away, in invoking the process of the sentencing circle in the Pauchay case, the Yellow Quill Community was, amongst others, attempting to ensure that Pauchay was sentenced within the framework of RJ. It can, however, be observed that the recommendations of the Yellow Quill Community entirely excluded custodial sentences in the form of imprisonment as an option in the sentencing discourse. It would therefore, appear that in the Yellow Quill Community's view, taking into account the values of RJ meant that punishment in all its forms ${ }^{904}$ was not an option. Again here, the Yellow Quill

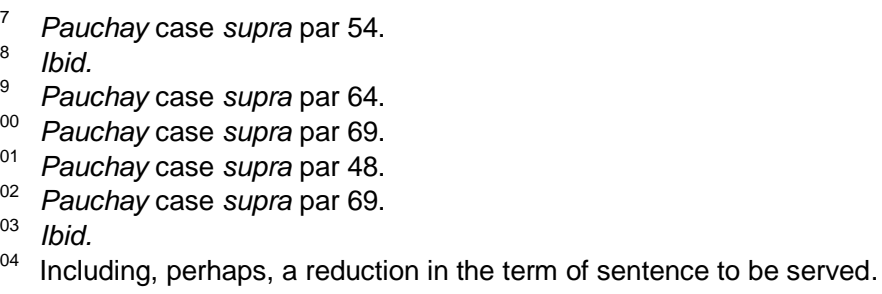


Community would appear to have set $\mathrm{RJ}$ up for failure because, totally excluding the option of imprisonment in a system that considers imprisonment fundamentally relevant in cases of serious offending, set the pace for the dichotomy between RJ and the conventional system of justice. This dichotomy ultimately, albeit implicitly, presented RJ and conventional sentencing as alternatives, with the Court having to choose between the two approaches.

Another important issue that can be deduced from the Pauchay case pertains to implications of the manner in which $\mathrm{RJ}$ is conceptualised by sentencing circles for the decision of the Courts on the role of RJ in cases of serious offending. Arguably, where sentencing circles view RJ as totally and strictly excluding punishment, early enough, they set the pace for a dichotomy, which the court then has to confront. As can be garnered in the Pauchay case, with the Yellow Quill Community having proceeded on the premise that RJ excludes punishment, the Court was placed in a precarious position, leading Morgan $\mathrm{J}$, the presiding judge, to disagree with the recommendations of the sentencing circle because to him, the offence in issue was very serious so much so that even if he was so inclined, the principle of denunciation needed to be fostered by some form of custodial sentence in the form of imprisonment. ${ }^{105}$ It is, perhaps, here that sentencing circles need to take a step back and to ponder: in making recommendations to the Court as to the appropriate sentence to be handed down for serious offenders, do the recommendations necessarily have to exclude punishment in the form of imprisonment? It does appear that most sentencing circles or RJ platforms, as can be gleaned in the Thabethe case too, proceed on the premise that recommendations to Court should always exclude punishment, notwithstanding the seriousness of the offence in issue. The implications of such an approach for cases of serious offending, however, cannot be overstated. Thus, sentencing circles should equally re-evaluate the manner in which RJ is conceptualised especially when dealing with cases of serious offending.

Mention needs to be made of some of the commentaries on the Pauchay case. The decision in this case, has provoked criticism, some commentators taking the view that it was a typical case of "[a]n objective 'failure' in the implementation of RJ practices". ${ }^{106}$ In light of such condescending criticism, one is again forced to take a step back and to question: a failure from what perspective? Of course, if $\mathrm{RJ}$ is conceptualized as an approach that strictly excludes all forms of punishment in the form of imprisonment, RJ was an absolute failure. But could, perhaps, these commentators have come to a different conclusion in respect of the Pauchay decision had they conceptualized RJ not necessarily as excluding punishment, and not merely as a sentencing option but rather a guiding principle in the overall criminal justice process which encompasses many other processes including victim participation, compensation, community participation and restitution? Other commentators have taken the view that for a crime as serious as the one

105 Pauchay case supra par 69.

106 Berlin "Restorative Justice Practices for Aboriginal Offenders: Developing an Expectationled Definition for Reform" 20163 Appeal 314. 
committed by Pauchay, a non-custodial sentence based on RJ would have been an "awkward fit" altogether and could just not have sufficed. ${ }^{107}$ The latter category of commentators, though vouching for the custodial sentence handed down, equally appears to endorse the view that RJ and custodial sentences are total opposites, hence their argument that sentencing within the restorative justice paradigm would have been an "awkward fit." Again, one wonders, if RJ were to be viewed as more than a sentencing option or, not necessarily an alternative or even as not excluding punishment per se, would these commentators still maintain this line of argument? Supposing one had to put himself or herself in the position of the presiding judge: would the judge have been placed in the precarious position of having to choose between RJ and the conventional goals of sentencing such as denunciation, separation and deterrence? Arguably, not. Overall, perhaps the time is about to come, and has perhaps come, for criminal justice professionals, commentators included, to find an equilibrium, with RJ not being perceived merely as a sentencing alternative or a threat to conventional approaches, but rather, an approach that can be tweaked with a view to resting comfortably alongside efforts geared towards confronting serious crimes. Such a proposal is arguably not ambitious. Indisputably, goals of RJ including having the victims' voice given due regard, emphasis on restitution, compensation etc. can do little or nothing to trivialize the seriousness of an offence such as rape or murder for that matter.

To summarise briefly, in all the cases discussed, it is argued that the Courts were correct in ruling that the cases in issue constituted very serious offences. These Courts ${ }^{108}$ were equally correct to indicate that in cases of serious offending, goals such as deterrence, denunciation, and separation were fundamentally relevant in the overall sentencing discourse. It is, however, submitted that these Courts (and sometimes the parties to these proceedings including the conveners of the sentencing circles), were not correct to reduce RJ (albeit implicitly) to a mere sentencing goal, a notion that is totally not on par with imprisonment and as an alternative to RJ. To do so was to reduce RJ to an alternative rather than a guiding principle in the overall criminal justice process. This also had the implication of placing judicial officers in a precarious position in which they had to choose between two systems of justice, an issue that should not have arisen in the first place. It is against this backdrop that the point is consistently being made that if $\mathrm{RJ}$ is to make a meaningful contribution in cases of serious offending, it ought not to be constructed as an approach that strictly excludes punishment or as an alternative to conventional sentencing, but rather, a guiding principle in the overall criminal justice process.

Without a doubt, RJ is a very wide concept and one that is subject to profound ambiguity. Nonetheless, it also bears some cross-cutting features, which if properly tweaked, can go a long way in complementing the criminal justice process in so far prosecution of serious offences is concerned. Notably, RJ presents opportunities including the offender making things

107 Libin 27 February 2009 National Post http://www.nationalpost.com/news/story. html?id=1337495.

108 Particularly the Thabethe, Pauchay, Gladue and Seedat Courts. 
rights as much as possible, addressing the needs of victims for validation/ vindication/ restitution/ support/ testimony, maximization of opportunities for exchange of information and participation, involvement of the community in decision-making and cognizance/ redress of the root causes of the crime in issue. ${ }^{109}$ Certainly, advancing these goals would not, whatsoever, undermine the seriousness of the offence. Notice that in all the cases where RJ was rejected by the courts, the courts did not attach any necessary importance to the overall benefits of RJ, thereby, negating other valuable benefits of RJ. Had these Courts conceptualized RJ as a concept not necessarily at loggerheads with the conventional system but rather as guiding principle, these courts would arguably not have arrived at the blanket conclusion that RJ has no place in cases of serious offending. The point emphasised, therefore, is that $\mathrm{RJ}$ is an approach to justice that can complement prevailing penal systems.

An issue that would, however, remain unresolved would be the implications of the above arguments for the prosecution of child offenders. As coherently argued thus far, if $\mathrm{RJ}$ is constructed liberally to not necessarily exclude punishment and as not merely a sentencing option, it would make a more meaningful contribution in cases of serious offenders. Put another way, the argument is that some form of punishment in the form custodial sentences may, in fact, pave the way for the better reception of RJ by the courts in cases of serious offending. However, what then happens to child offenders, where custodial sentences are generally considered to be measures of last resort for children? Should the same standards apply especially in light of legislation in place making the foregoing position explicit?

\section{RESTORATIVE JUSTICE AND CHILD OFFENDERS: PERSPECTIVES FROM SOUTH AFRICA AND CANADA}

It is generally accepted that in sentencing child offenders criminal justice systems ought to be more lenient than the case would be for adult offenders. Such an approach finds justification in a number of instruments, both national and international. Under section 28 of the Constitution of South Africa, in all matters or decisions pertaining to children, the best interest of the child is to be of paramount consideration. ${ }^{110}$ The emphasis placed on the best interest of the child is also highlighted by a number of international instruments to which South Africa is a party including the United Nations Convention on the Rights of the Child and the African Charter on the Rights and Welfare of the Child. ${ }^{111} \mathrm{~A}$ number of Court decisions have given

109 See generally United Nations Economic and Social Council (ECOSOC), UN Economic and Social Council Resolution 2002/12: Basic Principles on the Use of Restorative Justice Programmes in Criminal Matters, 24 July 2002, E/RES/2002/12, http://www.refworld. org/docid/46c455820.html (accessed 2017-03-5).

110 See the Constitution of the Republic of South Africa, 1996.

111 See articles 3 and 4 of the United Nations Convention of the Rights of the Child 1989 and the African Charter on the Rights and Welfare of the Child 1990. 
meaningful content to section 28 of the Constitution, one notable case being the Constitutional Court decision in $S$ v. $M$ where the Court ruled amongst others that:

"The ambit of the provisions [s 28(2) read with $s 28(1)$ ] is undoubtedly wide. The comprehensive and emphatic language of $s 28$ indicates that just as law enforcement must always be gender sensitive, so must it always be childsensitive; that statutes must be interpreted and the common law developed in a manner which favours protecting and advancing the interests of children; and that courts must function in a manner which at all times shows due respect for children's rights."

Giving due regard to the best interest of the child, it is to be expected to encompass children's best interests when they come into contact with the criminal justice system as offenders. At the sentencing stage, the principle of the best interest of the child would constitute one of the considerations in the determination of the appropriate sentence. South Africa has enacted a law to further augment the special protection to be accorded to child offenders- The Child Justice Act. ${ }^{113}$ This Act, establishes a criminal justice system for child offenders, which is separate from the mainstream criminal justice system. ${ }^{114}$ The Act is essentially anchored in a RJ approach to child offenders. ${ }^{115}$ The sentencing of child offenders in accordance with this Act is regulated by chapter 10 of the Act. Section 68, which constitutes the first section in chapter 10 provides that "A child justice court must, after convicting a child, impose a sentence in accordance with this Chapter." The chapter, amongst others, encourages the use of diversion when dealing with child offenders. It also underscores that child offenders should be treated more leniently than adult offenders. ${ }^{116}$ Generally, when it comes to child offenders, the Act envisages custodial sentences in the form of imprisonment as a measure of last resort. ${ }^{117}$ Diversion in terms of the Child Justice Act connotes an approach where children are not subjected to formal criminal proceedings. ${ }^{118}$ Accordingly, alternative avenues for addressing the crimes committed by children are explored, with RJ constituting one of such options. According to commentators, the Child Justice Act is a true representation of efforts to anchor justice for child offenders within an RJ paradigm. ${ }^{119}$ Put another way, $\mathrm{RJ}$ is a mandated consideration in terms of the Child Justice Act.

The issue that would fail to be resolved then would be: in light of the consistent argument that RJ should be conceptualized as a notion not

112 S v M supra par 15

113 See the Child Justice Act 75 of 2008 (CJA).

114 See generally CJA.

115 The Act, under its preamble, defines RJ as "an approach to justice that aims to involve the child offender, the victim, the families concerned and community members to collectively identify and address harms, needs and obligations through accepting responsibility, making restitution, taking measures to prevent a recurrence of the incident and promoting reconciliation."

116 See Chapters 6 and 8 CJA.

117 S 69(1)(e) CJA.

118 Preamble to CJA.

119 See eg, Van der Merwe "A New Role for Crime Victims? An Evaluation of Restorative Justice Procedures in the Child Justice Act 2008" 2013 De Jure 1022-1038. 
necessarily excluding punishment; and that in cases of serious offending, the goals of deterrence, separation and denunciation should be given due regard, what would be the implication of such an argument for the sentencing of children who commit serious offences? In light of the fact that section 28(2) of the Constitution requires due regard to be accorded to the best interests of the child "in every matter concerning the child" ${ }^{20}$ (which would certainly encompass criminal law and criminal justice), it is submitted that the child offender's best interests should equally play a key role in the determination of the nature of sentence to be handed down against the child offender in a case of serious offending. It is a consideration that must be given practical effect whenever a court is confronted with the task of balancing goals such as deterrence, separation and denunciation on the one hand, and diversion ${ }^{121}$ of child offenders on the other. Arguably, it should generally be the principle as a practical matter that, despite the crime being a serious one, child offenders should not be sentenced to custodial sentences even though $\mathrm{RJ}$ is conceptualized as not necessarily barring punishment.

In Canada, although the issue of RJ has predominantly featured in cases pertaining to aboriginal offenders, it equally constitutes a prominent approach in cases involving young offenders. In 2003, Canada enacted the Youth Criminal Justice Act. ${ }^{22}$ This Act establishes a criminal justice system for young persons that is separate from that of adults. ${ }^{123} \mathrm{~A}$ young offender for purposes of the Youth Criminal Justice Act connotes a person who "appears to be twelve years old or older, but less than eighteen years old." ${ }^{124}$ The system established under this Act has an eye for RJ and in fact encompasses a range of provisions geared towards advancing the goals of RJ. Notably, the Act makes provision for extra-judicial measures. ${ }^{125}$ These constitute "measures other than judicial proceedings under [this Act] used to deal with a young person alleged to have committed an offence and includes extrajudicial sanctions." ${ }^{\text {26 }}$ The Act amongst others, underscores the use of approaches that encourage the repair of harm done to victims and the community. ${ }^{127}$ The foregoing approach, by all means does not exclude RJ as one of the approaches to advance this goal. Of specific importance to the matter under discussion is the fact that the Act underscores that when dealing with young offenders, incarceration and all forms of custodial sentences should constitute measures of last resort. ${ }^{128}$ Where custodial sentences are considered, the Youth Justice Court is mandated to give reasons why it deemed such a sentence fit for a young offender. ${ }^{129}$ Moreover, even when young offenders are sentenced, the general position

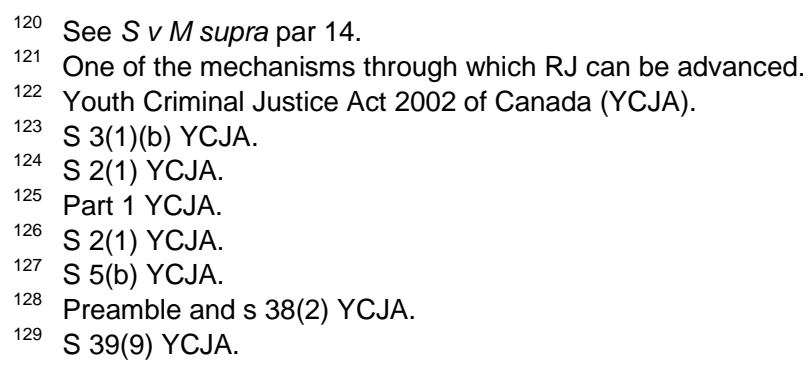


under the Youth Criminal Justice Act is that "the sentence must not result in a punishment that is greater than the punishment that would be appropriate for an adult who has been convicted of the same offence committed in similar circumstances." 130 This reinforces the notion that children are generally to be treated more leniently than adult offenders in so far as criminal justice is concerned.

Significant to note, however, although this Act provides that custodial sentences in the form of incarceration should constitute measures of last resort when it comes to offenders, the Act also makes it explicit that incarceration should still be reserved for the most serious offences. ${ }^{131}$ In addition, even with a provision for extra-judicial measures for young offenders, the Act further underscores that if the young offender has committed a serious crime, these measures do not suffice. ${ }^{92}$ Rather, they are reserved for young offenders who have committed minor crimes. In fact, the Act gives the Youth Justice Judge the discretion to detain a young person charged with a serious crime notwithstanding the Act's position on incarceration as a measure of last resort. ${ }^{133}$ From the foregoing position, it would appear that the Youth Criminal Justice Act still maintains the position that the young age of the offender does not per se exonerate the young offender from incarceration. The emphasis that young offenders are not to benefit from extra-judicial measures, or, that they are to be detained rather than granted non-custodial sentences, are only a few examples of how the YCJA treats criminally-accused youth more like adult accused criminals. Essentially, where the offence at issue is a serious one, the goals of deterrence, separation and denunciation still take precedence as the position is for adults. As one commentator has pointed out, the Youth Criminal Justice Act of Canada replaced the earlier model that predominantly comprised of a child-welfare model of justice with a "more legalistic and punitive 'justice' and 'crime-control' models of juvenile justice procedure." ${ }^{134}$ This commentator adds, correctly so, "it appears that under the YCJA concern for the general welfare or 'best interests' of children has been made subordinate to concerns with holding young criminals more accountable (like adults) and managing them in custody."

This takes us back to the issue that formed the crux of this last section: in light of the consistent argument to the effect that RJ should not be necessarily conceptualized as an approach that precludes the invocation of custodial sentences, should the same standard be applied to children? As briefly discussed in the preceding paragraph, although the Canadian Youth Criminal Justice Act makes room for RJ to be invoked in cases pertaining to young offenders, when it comes to cases of serious offending, the Act appears to be more legalistic and in advancement of punitive justice than

\footnotetext{
S 38(2)(a) YCJA.

S 39(1)(a) YCJA.

$S 4(c)$ YCJA.

S 39(1) YCJA

134 Smandych "Canada: Repenalization and Young Offenders' Rights" 2006 Contemporary Youth Criminal Justice: Critical Issues 1920.

135 Smandych 2006 Contemporary Youth Criminal Justice: Critical Issues 26.
} 
would be acceptable when dealing with child offenders. It is pertinent to note here that Canada, as the case is for South Africa, is party to the UNCRC. In fact the Canadian Youth Criminal Justice Act makes mention of the UNCRC as well as this State's obligations under this Act. ${ }^{136}$ Worthy to mention, the UNCRC makes it explicit that the principle of the best interest of the child should be a primary consideration in all matters and decisions pertaining to children. It is, therefore, submitted that by virtue of ratification of the UNCRC, Canada is bound to deal with child offenders, even in cases of serious offending, in a manner that takes due cognizance of the best interest of the child. ${ }^{137}$ Where emphasis is on punishment of the young offender, merely because the crime in issue is a serious one, arguably the State would have failed in its obligations in so far the principle of the best interest of the child is concerned.

\section{CONCLUSION}

The purpose of this discussion was to assess the manner in which RJ has played out in Canadian and South African courts, specifically in cases of serious offending. The analysis confirms that the practice of the courts in both Canada and South Africa has been to perceive RJ and retributive justice as alternatives, to view RJ as incompatible with punishment in the form of custodial sentences, and to reduce RJ to a mere sentencing option. An analysis of the practice of these courts also suggests that in conceptualizing RJ as such, RJ often ends up being excluded from the overall criminal justice process. There also seems to be a general presumption that invoking $\mathrm{RJ}$ in cases of serious offending will undermine the seriousness of these crimes. This in turn, suggests that as long as RJ is perceived as an approach that is totally against the values of retributive justice, its role will most likely continue to be undermined, particularly in cases of serious offending. It is against this backdrop that a conclusion is drawn that: courts should perceive RJ as a guiding principle in the overall criminal justice process. This way, RJ will more easily blend with retributive justice, particularly in cases of serious offending where it has popularly, albeit problematically, been reduced to an approach that is "soft" on crime. The discussion, however, takes the view that emphasis on custodial sentences, as a means of making RJ more acceptable by contemporary criminal justice systems should not lose sight of the general presumption that in cases involving child offenders, custodial sentences should be a measure of last resort. The best interest of the child, a principle that both Canada and South Africa consider paramount, lends impetus to an argument that child offenders should be accorded special consideration or rather treated more leniently than adult offenders.

Preamble YCJA.

137 This is accordance with article 26 of the Vienna Convention on the Law of Treaties of 1969 that entrenches the Pacta Sunt Sevanda rule, to the effect that "[e]very treaty in force is binding upon the parties to it and must be performed by them in good faith". 